\title{
Microbial Diversity among Azotobacter strains and Efficacy Test on Chickpea (Cicer arietinum)
}

\author{
Jitendra Malviya ${ }^{1 *}$ and Bhupendra $\operatorname{Prasad}^{2}$ \\ ${ }^{I}$ Department of Biotechnology and Bioinformatic centre, \\ Barkatullah University, Bhopal, India \\ ${ }^{2}$ Department of Microbiology, Career College, Bhopal, India \\ *Corresponding author
}

Keywords

Azotobacter, nitrogenase, PGPR, PCR, 16S-rDNA, Phylogenetic analysis,

Dendrogram

Article Info

Accepted:

10 March 2020

Available Online:

10 April 2020

Non-symbiotic (Azotobacter) nitrogen obsession is a critical wellspring of settled nitrogen for the biosphere. Microorganisms catalyze natural nitrogen obsession with the chemical nitrogenase, which has been exceedingly moderated through development. Aside from settling nitrogen Azotobacter can be utilized as a plant development advancing rhizobacteria (PGPR). Soil tests were gathered from differing agrarian documented of Misrod (District Raisen) Bhopal (Madhya Pradesh). The dirt example were chosen from Rhizospheric locale of Cicer arietinum, speak to an extensive variety of physical and compound properties, $16 \mathrm{~S}$ rDNA based PCR Amplification method were utilized for quality articulation. Confined protein (Alu I,) favored for RFLP and RAPD (OPK 20) 5'GTGTCGCGAG-3'primer for fingerprinting and gives a high level of segregation between Azotobacter species. Phylogenetic examination16S-rDNA based PCR and elucidation in the wake of anticipating dendrogram changes of Azotobacter strains acquired affirms varieties among species. Presence of variable game plan on genome by reflecting slight variety coming about into foundation of decent variety among strain.

\section{Introduction}

There is awesome assorted variety in the metabolic kinds of free-living microorganisms, which are fit for BNF. This incorporates around 20 genera of nonphotosynthetic oxygen consuming (Azotobacter, Beijerinckia) and anaerobic
(Clostridium) microscopic organisms and around 15 genera of photosynthetic cyanobacteria (blue green growth, for example, Anabaena and Nostoc. Free-living, non-photosynthetic microbes rely upon soil natural issue as a sustenance source though the photosynthetic microorganisms may get their nourishment from the results of 
photosynthesis. The nitrogen settling action of free-living, non-photosynthetic, vigorous microorganisms are firmly reliant on great dampness conditions, oxygen, and a natural sustenance source. Anaerobic delegates (Clostridium) prevail in field and waterlogged soils and soil totals where dampness conditions and natural substrates are accessible yet oxygen supply to the microenvironment of the microscopic organisms is extremely confined. The underlying foundations of such plants may supply the nitrogen-settling microorganisms with a moderately high and managed supply of nourishment (photosynthetic), or, in other words restricted supply in the rhizosphere of generally plants.

Free-living nitrogen-settling anaerobic microbes are available and settle nitrogen in the intestinal substance of an assortment of creatures (herbivores) and furthermore man. Nitrogenase activity is generally quite low and its significance in terms of satisfying nutritional requirements of the host appears doubtful. Most nitrogen-fixing bacteria (typically members of the genus Rhizobium) form symbiotic associations with leguminous plants, where they are provided with nutrients by the plant and simultaneously protected from oxygen, which poisons the enzyme required for nitrogen fixation (nitrogenase Azotobacter species are Gram-negative, aerobic soil-dwelling bacteria.

They are typically polymorphic, i.e. of different sizes and shapes. Their size of the cells ranges from $2-10 \mu \mathrm{m}$ long and $1-2 \mu \mathrm{m}$ wide Old cells tend to form thick-walled, optically retractile cysts, which have capsules consisting largely of alginates and other polysaccharides, enhancing their resistance to heat, desiccation and adverse environmental conditions. (Malviya et al., 2017) Improvements in sub-atomic science based procedures have prompted quick and dependable instruments to portray microbial network structures and to screen their elements under in situ conditions RAPD remains for Random Amplification Polymorphism DNA. RAPD responses are PCR responses, however they open up portions of DNA, which are basically obscure to the researcher (irregular).

PCR is utilized to open up a known grouping of DNA. Along these lines, PCR prompts the intensification of a specific section of DNA Bacterial provinces in Petri dishes yet at last obtained an arms stockpile of sub-atomic DNA based methods that enable them to watch the living beings in their indigenous habitats. Microbial creature are considerably more differing then we at any point envisioned (Cheryl kuske et al., 2005) see how tremendous that assorted variety may be microscopic organisms are basic for breaking down and reusing supplements at a worldwide scale.

The method for distinguishing these new microbes includes removing and sequencing one quality from every one of the microorganisms in an ecological example. The 16S qualities are the marker. Novel devices to describe populaces in soil' created and enhanced devices to examine nitrogensettling microorganisms in soil, with an accentuation on the free-living (Asymbiotic) populace. Chickpea (Cicer arietinum L.) (Malviya et al., 2018) is an important leguminous crop of Indian subcontinent. It has been grown in India for times immemorial. The rhizobia comprise a diverse group of organisms that bring forth hypertrophic growth on the roots of legume plants to form a new organ, the root nodule, which they reside in to fix nitrogen. Although the root nodule structure can develop without bacterial infection but infection and organogenesis normally proceed simultaneously. Nodule development is under 
control of specific nodulation (nod) signal(s) produced by rhizobia in response to the secretion of phenolic compounds by host plant. A marker quality of nitrogen-settling microorganisms (nifH) was utilized as a subatomic marker to consider the decent variety, and by means of the discovery of mRNA, additionally the action of these life forms in soil. This methodology permits to connect auxiliary data about a microbial network specifically to the visibly recognizable action of nitrogen obsession.

This methodology gives a vital apparatus to connect the structure-action hole that speaks to a noteworthy test to current microbial environment. Various strategies were created to propel this innovation: To evaluate the assorted variety of this utilitarian quality and its appearance, nucleic acids (DNA and RNA) must be removed from soil a basic advance on which every single downstream investigation depend. Enhanced conventions for powerful extraction of DNA and RNA from soil were created.

Various investigations duplicates of this quality creating $16 \mathrm{~s}$ quality. Trouble in concentrate such a significant number of life forms they have created network fingerprinting methods, basically coding at the issue at a much lower goals (Malviya et al., 2012). This sub-atomic unique finger impression examination can be utilized to screen bacterial many-sided quality the relative plenitude and elements of these infinitesimal networks at a scene level in reality.

Another outskirt of science is developing that joins science the investigation of normal items from already uncultured soil microorganisms. The methodology Involves straightforwardly getting to the genomes of soil living beings that can't be, or have not been, refined by secluding their DNA, cloning it into cultural creatures and screening the resultant clones for the generation of new synthetic substances. The fervor encompassing this new field lies in the huge decent variety of obscure soil miniaturized scale verdure and the substance lavishness that they are thought to contain. In order to develop bioinoculants, both metabolic fingerprinting and genetic fingerprinting have been used to study the diversity among Azotobacter spp. Isolated different district of Madhya Pradesh.

\section{Materials and Methods}

\section{Sampling site}

Soil samples were collected from 10 different agricultural filed of Misrod (District Raisen) Bhopal (Madhya Pradesh). Rhizospheric region of Cicer arietinum, the soil sample were selected to represent a wide range of physical and chemical properties. (Malviya et al., 2011)

\section{Isolation of free-living nitrogen fixing bacteria}

Dilution series was made ranging from $10^{-1}$ to $10^{-9}$ Colonies growing on Jensen's agar medium. The procedure followed for isolation of Azotobacter strains from soil, purification of culture and authentication test were as described Vincent (1970). The colony were isolated is off-white, white, yellow and some are in lemon color, consistency is soft, some are opaque, and shiny with regular and irregular marginal.

\section{Germination of seed}

The investigation was spread out in a Complete Randomized Design with four replication. The parameters considered were germination percent (\%), germination list, shoot length $(\mathrm{cm})$, root length $(\mathrm{cm})$, seedling 
length $(\mathrm{cm})$, seedling crisp weight $(\mathrm{g})$, seedling dry weight $(\mathrm{g})$, force file I and II. Perceptions were recorded on five haphazardly chosen seed for every one of the parameters from every replication.

The execution of natural and inorganic development controllers was assessed on premise of research facility germination test by gathering distinctive germination parameters viz., germination per cent $(\%)$, germination file, shoot length $(\mathrm{cm})$, root length $(\mathrm{cm})$, seedling length $(\mathrm{cm})$, new weight of seedling (gm), dry weight of seedling (gm), seed life record I, and seed power file II. These parameters were measurably examined and basic contrasts were determined.

\section{DNA isolation}

For total genomic DNA isolation, culture of Azotobacter was grown for $24 \mathrm{~d}$ at $28^{\circ} \mathrm{C}$ in Jensen's agar medium. Cells were pelleted several times by centrifugation at $10000 \mathrm{rpm} / 10 \mathrm{~min}$. Add $1 \mathrm{ml}$ of $50 \mathrm{mM}$ Tris (pH-8.0) and $1 \mathrm{ml}$ of $50 \mathrm{mM}$ EDTA and dissolved the pellet.

Freeze it in deep freezer at $-20^{\circ} \mathrm{C}$ for $30 \mathrm{~min}$ and add $0.5 \mathrm{ml}$ of $250 \mathrm{mM}$ tris base $(\mathrm{H}-8.0)$ $10 \mu \mathrm{l}$ of $10 \mathrm{mg} / \mathrm{ml}$. Lysozyme and then place on ice for $45 \mathrm{~min}$.

Add $0.5 \mathrm{ml}$ of $0.5 \%$ SDS, $0.5 \mathrm{ml}$ of $50 \mathrm{mM}$ Tris (pH-8.0), $0.5 \mathrm{ml}$ of $0.4 \mathrm{~m}$ EDTA, add $10 \mu \mathrm{l}$ of $1 \mathrm{mg} / \mathrm{ml}$ of proteinase $\mathrm{K}$ place in water bath at $50^{\circ} \mathrm{C}$ for $60 \mathrm{~min}$. Put $3 \mathrm{ml}$ of phenol \& centrifuge at 10000rpm /15 min. Transfer the top layer to new tube (Avoid interference). Add 0.1 volumes of $3 \mathrm{M}$ sodium acetate mix gently and then add 2 volume of $95 \%$ ethanol mix by inverting spool out DNA \& Transfer to $1.5 \mathrm{ml}$ Eppendorff. Put $0.5 \mathrm{ml} 50 \mathrm{mM}$ tris.5) $0.5 \mathrm{ml} 1 \mathrm{mM}$ EDTA. Dissolve overnight by rocki8ng at $4^{\circ} \mathrm{C}$. Add $10 \mu \mathrm{l}$ RNAse and incubated for 1 hour at $37^{\circ} \mathrm{C}$ Extract with equal volume of chloroform mix by inverting take top layer in new tube after centrifuged at $10000 \mathrm{rpm} / 5 \mathrm{~min}$. Add 0.1 volume $3 \mathrm{M}$ sodium acetate (mix gently) and the add 2 vol. 95\% ethanol. Spool out DNA \& Dissolve in $60 \mu 1$ TE buffer $(\mathrm{pH}-8.0)$ the concent5ration and the purity of DNA were estimated spectrophotometrically at 260 and $280 \mathrm{~nm}$ (Malviya et al., 2018)

\section{PCR of the isolated DNA}

Two different Oligonucleotide primers, obtained from (Pharmacia Biotech ltd.) were chosen arbitrarily. All the primers used in this work were 10 nucleotides in length and has a good GC content of $70 \%$. Primers sequences (5'to 3') were as follow FDI (5' CCG AAT TCG TCG ACA ACA GAG-3') and RDI (5'CCC GGG ATC CAA GCT TAA G -3') DNA amplification was done in thermal cycler (Mini Cycler, TM MJ Research PTC100).

With the following temperature profile an initial Denaturation $\left(94^{\circ} \mathrm{C}\right.$ for 5 minutes), 30 cycles of Denaturation (30seconds a $94^{\circ} \mathrm{c}$ ), annealing $\left(50^{\circ} \mathrm{C}\right.$ for 40 seconds) and extension $\left(72^{\circ} \mathrm{C}\right.$ for 90 seconds) and a final extension ( $72^{\circ} \mathrm{C}$ for 7 minutes). For every PCR reaction, a negative control (no template DNA) and a positive control (Template, DNA giving amplified product) were in variably maintained. The amplified product was run on a $0.8 \%$ agarose gel along with $1 \mathrm{~Kb} \mathrm{MW}$ marker, at a constant voltage and visualized under UV light (Uvitch Gel Documentation system) (Malviya et al., 2018).

\section{RFLP (Restriction fragment length polymorphism)}

Amplified product (17ul of the PCR mix) was digested with 1unit of restriction endonucleases (Alu I) according to the manufacturer's recommendations). 
Restriction Fragments were separated on a $2.5 \%$ agarose gel and stained with ethidum bromide. A 100 bp DNA Ladder was used as molecular weight marker.

\section{RAPD analysis random amplified polymorphic DNA}

The procedure described by (Williams et, al., 1990) with minor modification was used for caring out PCR reaction to produce RAPD profiles. Amplification of DNA fragments was carried out by the Polymerase Chain reaction were carried out using the same DNA as used for 16s rDNA. The reaction mixture consisted of $200 \mu \mathrm{M}$ of dNTP mix 15 pico mole of primer, $1 \mathrm{U} / \mu \mathrm{l}$ of Tag DNA polymerase and $25 \mathrm{mM} \mathrm{MgCl}_{2}$. (OPK 20) $15^{\prime}$ GTGTCGCGAG-3' was selected because it was able to differentiate among isolates.

\section{Scoring and data analysis}

The extent of every limitation part or RAPD piece was computed and the profiles of the strains were analyzed groups of sections shorter than $90 \mathrm{bp}$ were not mulled over since they were not settled reproducibly. Each band created with a specific limitation chemical or RAPD groundwork was scored over every one of the examples.

Information was entered utilizing $0-1$ grids in which every watched band or characters were recorded. The RFLP example and RAPD profile of each confine was assessed doling out character state "1" was given for a band, which could be unmistakably and reproducibly recognized in the RFLP or RAPD examination. The date lattice subsequently created was utilized to figure Jacard's similitude coefficient for each match insightful correlation. The coefficient was figured after recipe (Jaccard, 1908). The unweighted combine aggregate built Dendogram from the closeness network.
Technique with number juggling means averaging (UPMGA) (Sneath and Sokal, 1973). With the end goal to test the integrity of attack of group investigation, cophenetic esteem network were ascertained and contrasted and the first closeness lattice that were UPMGA bunched by utilizing the NTSYS-pc examination bundle (Version 1.3, Exeter programming Setauket, N.Y.) (Malviya et al., 2012)

\section{Results and Discussion}

Hereditary decent variety of Azotobacter species from agribusiness field of Raisen area of M.P. is completed in the wake of accommodating properties of soil from various testing destinations. Azotobacter is a variety, or, in other words set up free-living nitrogen settle additionally (Asymbiosis) with rhizospheric locale which is controlled by quality item. The dirt qualities impact the event of rhizospheric district and natural nitrogen obsession. Test got from locales A1 A2 A3 altogether broke down in the research center with existing strategy.

\section{Isolation of Azotobacter}

Tests acquired from rhizospheric region of Cicer Arietinum, and exchanged to predisinfected holders and named by locales. The way of life was developed and keeps up on Jensen's medium at $28^{\circ} \mathrm{C}$ for 20 mins. Culture qualities of Azotobacter are exhibited in Table 1. Besides morphological investigations by gram recoloring are analyzed and gram negative bars are seen. Development of all separated strain was performed in presterlized stock and strains were assigned as moderate developing species (Table 1).

All the gathered Azotobacter strains were indistinguishable however displayed variety in development and physiological qualities. All grayish white, yellow bacterial states and 
demonstrated existences of Azotobacter species none of the confine gave positive outcome for gelatin liquefaction test. Social and biochemical test fill in as sign to recognize the dirt microorganism. Following the premise of biochemical corroborative records the secluded Azotobacter strains from farming field were subjected to hereditary decent variety investigation.

Hereditary substance of life form uncovers its situation in natural decent variety general the microscopic organisms including free-living nitrogen fixers. Rhizospheric soil additionally occupies bacterial decent variety straightforwardly affected by topographical and natural elements. Portrayals of people are administered by articulation of hereditary pool which thus underpins position of people in transformative progressive system. Alteration of hereditary setup requires the advancement in species involving useful living space.

Hereditary decent variety of Azotobacter species from horticulture field of Raisen area of M.P. is done subsequent to accommodating properties of soil from various testing destinations. Azotobacter is a variety, or, in other words builds up free-living nitrogen settle likewise (Asymbiosis) with rhizospheric locale which is dictated by quality item. The dirt qualities impact the event of rhizospheric district and natural nitrogen obsession. Test got from destinations A1 A2 A3 altogether broke down in the lab with existing strategy.

\section{Characterization of Azotobacter}

Tests got from rhizospheric area Cicer Arietinum, and exchanged to pre-cleaned holders and named by destinations. The way of life was developed and keeps up on Jensen's medium at $28^{\circ} \mathrm{C}$ Culture attributes of Azotobacter are introduced in Table 1. Moreover morphological investigations by gram recoloring are analyzed and gram negative bars are seen. Development of all separated strain was performed in presterlized soup and strains were assigned as moderate developing species (Table 1).

All the gathered Azotobacter strains were indistinguishable however shown variety in development and physiological attributes. The grayish, white, yellow bacterial states and demonstrated existences of Azotobacter species. None of the detach gave positive outcome for gelatin liquefaction test. Social and biochemical test fill in as sign to recognize the dirt microorganism. Biochemical corroborative records the detached Azotobacter strains from horticultural field were subjected to hereditary decent variety investigation.

Hereditary substance of creature uncovers its situation in natural assorted variety general the microbes including free-living nitrogen fixers. Rhizospheric soil likewise possesses bacterial decent variety straightforwardly impacted by geological and organic variables. Portrayals of people are represented by articulation of hereditary pool which thusly bolsters position of people in transformative chain of command. Adjustment of hereditary setup requires the advancement in species involving useful territory.

Biochemical confirmatory records the isolated Azotobacter strains from agriculture field were subjected to genetic diversity analysis Genetic content of organism reveals its position in biological diversity general the bacteria including free-living nitrogen fixing nitrogen fixing rhizospheric soil also occupied bacterial Morphological characterization indicated a close resemblance of these isolates to Azotobacter spp. BIOLOG cataloguing divided them into two main groups, but amplified ribosomal DNA restriction analysis clustered the isolates from the four regions 
having different soil types into different district of Madhya Pradesh.

\section{Germination record}

The information uncovered that speed of germination demonstrates critical distinction among the different medications. The speed of germination ran from 11.58 to 15.00 .The most extreme speed of germination (15.00) was seen in JM-8 (GA3 20 ppm) which was observed to be essentially predominant pursued by JM-7 (GA3 10 ppm) 14.75 though, least speed of germination was recorded in charge to (11.58). The most extreme speed of germination with GA3 may be because of its impact in early germination and expanded percent germination. The outcomes are in similarity with discoveries of Rajamanickam and Anbu (2001) (Fig. 1 and 2).

The root length, shoot length and seedling length changed altogether in every one of the medications as contrasted and control during the investigation. It was biggest in joined impacts of bio manures over control and the individual impact of every alteration independently. Most noteworthy root length, precise advancement of plants and seeds shoot length and seedling length with use of Azotobacter, PSB and FYM in individual and in consolidated impacts of these demonstrates that these small scale atoms helps in the possibility of plant to endure well even in worry of dampness, effectiveness of supplements take-up and even mechanical help to the plant against rapid breezes and tempests in stormy season; likewise shoot length during testing shows the proficiency of speed of germination and furthermore better development and leaves improvement.

Despite the fact that maize has all around created vascular packs and stomata for effective physiological procedures including admission of climatic $\mathrm{CO} 2$ for usage of photosynthetic pathways of $\mathrm{C} 4$ cycles. These three characters are generally significant for generation purpose of perspectives as they are fundamentally and emphatically connected with development and yield parameters and aides in foundation of sound plants in fields oppressed for creation.

Germination rate was exceptionally impacted because of different medicines over control. It may be ascribed because of increasingly efficient improvement of sound fetuses in seeds and the amassing of supplements in seeds which helps in improving the level of germination and which were qualified according to standard of germination endorsed by affirmation principles. Different medicines appeared beneath $90 \%$ germination rate.

Maize is cross pollinated crop and planted in more extensive dispersing consequently poor germination will influences the plant stand per unit region coming about poor collect. Higher the estimations of germination in T4 for example with PSB pursued by Azotobacter (93.67\%) and PSB+ FYM blends $(92.67 \%)$ individually. These qualities satisfy the germination guidelines recommended for maize. Different medicines demonstrated this worth less consequently $90 \%$ and non-critical numerically over control. Higher the germination $\%$ for PSB, Azotobacter and consolidated impact of PSB+FYM showed that PSB, Azotobacter and blend of $\mathrm{PSB}+\mathrm{FYM}$ is useful in solid embryonic advancement and furthermore in dynamic translocation of nourishments integrated during photosynthesis in leaves to kernels (Table 2).

The seed treated with GA3 20 ppm was observed to be the most appropriate development controller for germination and energy of chickpea since it uncovered 
predominant execution in a large portion of the parameter viz., germination percent $(97.50 \%)$, germination file (15.00), shoot length $(17.87 \mathrm{~cm})$, root length $(15.89 \mathrm{~cm})$, seedling length $(33.07 \mathrm{~cm})$, seedling new weight $(7.71 \mathrm{~g})$, seedling dry weight $(1.54 \mathrm{~g})$, life file I (3223.03) and force file II (149.93).

\section{DNA isolation and PCR}

Genomic DNA of 24 isolated culture of Azotobacter were ornamental of $0.8 \%$ agarose gel electrophoresis and purity of DNA were estimated spectrophotometrically at 260and 280nm (Fig. 3). A novel molecular strategy for studying microbiological diversity is based on restriction digestion of $16 \mathrm{~S}$ rDNA sequence were separated on a $2.5 \%$ agarose gel and stained with ethidum bromide and visualized under UV light. The $16 \mathrm{~S}$ rDNA of 24 isolated strains war PCR amplified with universal primers (5'-CCG AAT TCG TCG ACA ACA GAG-3') and (5'-CCC GGG ATC CAA GCT TAA G-3').

Table.1 Biochemical characterization of free-living nitrogen fixing bacteria

\begin{tabular}{|c|c|c|c|c|c|c|c|c|c|c|}
\hline S.No & Strain & $\begin{array}{l}\text { Jensen } \\
\text { media }\end{array}$ & $\begin{array}{l}\text { Gram } \\
\text { staining }\end{array}$ & $\begin{array}{l}\text { Bacteria } \\
\text { colonies }\end{array}$ & $\begin{array}{l}\text { Hoffer's } \\
\text { alkaline } \\
\text { medium } \\
\text {-ve }\end{array}$ & $\begin{array}{l}\text { Glucose } \\
\text { peptone } \\
\text {-ve }\end{array}$ & $\begin{array}{l}\text { Ketola } \\
\text { ctose - } \\
\text { ve }\end{array}$ & $\begin{array}{l}\text { Liquefi- } \\
\text { ction of } \\
\text { gelatin }\end{array}$ & $\begin{array}{l}\text { Incubation } \\
\text { period at } \\
\text { for period } \\
\text { in } 28 \pm 1 \text { in } \\
\text { Hrs. }\end{array}$ & $\begin{array}{l}\text { S/M } \\
\text { Slow/ } \\
\text { moderate }\end{array}$ \\
\hline 1. & JM1 & + & -ve rod & Off white & $-v e$ & $-v e$ & $-\mathrm{ve}$ & $-\mathrm{ve}$ & 96 & $\mathbf{S}$ \\
\hline 2. & JM2 & + & -ve rod & white & $-\mathrm{ve}$ & $-\mathrm{ve}$ & $-\mathrm{ve}$ & $-\mathrm{ve}$ & 96 & $\mathbf{S}$ \\
\hline 3. & JM3 & + & -ve rod & Off white & $-\mathrm{ve}$ & $-\mathrm{ve}$ & $-\mathrm{ve}$ & $-\mathrm{ve}$ & 96 & $\mathbf{S}$ \\
\hline 4. & JM4 & + & -ve rod & Off white & $-\mathrm{ve}$ & $-\mathrm{ve}$ & $-\mathrm{ve}$ & $-\mathrm{ve}$ & 96 & $\mathbf{S}$ \\
\hline 5. & JM5 & + & -ve rod & Off white & $-v e$ & $-\mathrm{ve}$ & $-\mathrm{ve}$ & $-v e$ & 96 & $\mathbf{S}$ \\
\hline 6. & JM6 & + & -ve rod & Yellow & $-\mathrm{ve}$ & $-\mathrm{ve}$ & $-\mathrm{ve}$ & $-\mathrm{ve}$ & 96 & $\mathbf{S}$ \\
\hline 7. & JM7 & + & -ve rod & Off white & $-v e$ & $-\mathrm{ve}$ & $-\mathrm{ve}$ & $-\mathrm{ve}$ & 96 & $\mathbf{S}$ \\
\hline 8. & JM8 & + & -ve rod & Off white & $-\mathrm{ve}$ & $-\mathrm{ve}$ & $-\mathrm{ve}$ & $-\mathrm{ve}$ & 96 & $\mathbf{S}$ \\
\hline 9. & JM9 & + & -ve rod & Yellow & $-v e$ & $-\mathrm{ve}$ & $-\mathrm{ve}$ & $-\mathrm{ve}$ & 96 & $\mathbf{S}$ \\
\hline 10 & JM10 & + & -ve rod & White & $-v e$ & $-\mathrm{ve}$ & $-\mathrm{ve}$ & $-\mathrm{ve}$ & 96 & $\mathbf{S}$ \\
\hline 11 & JM11 & + & -ve rod & White & $-v e$ & $-\mathrm{ve}$ & $-\mathrm{ve}$ & $-\mathrm{ve}$ & 96 & $\mathbf{S}$ \\
\hline 12 & JM12 & + & -ve rod & White & $-\mathrm{ve}$ & $-\mathrm{ve}$ & $-\mathrm{ve}$ & $-\mathrm{ve}$ & 96 & $\mathbf{S}$ \\
\hline 13 & JM13 & + & -ve rod & Lemon & $-\mathrm{ve}$ & $-\mathrm{ve}$ & $-\mathrm{ve}$ & $-\mathrm{ve}$ & 96 & $\mathbf{S}$ \\
\hline 14 & JM14 & + & -ve rod & Off white & $-\mathrm{ve}$ & $-\mathrm{ve}$ & $-\mathrm{ve}$ & $-\mathrm{ve}$ & 96 & $\mathbf{S}$ \\
\hline 15 & JM15 & + & -ve rod & Off white & $-\mathrm{ve}$ & $-\mathrm{ve}$ & $-\mathrm{ve}$ & $-\mathrm{ve}$ & 96 & $\mathbf{S}$ \\
\hline 16 & JM16 & + & -ve rod & Off white & $-\mathrm{ve}$ & $-\mathrm{ve}$ & $-\mathrm{ve}$ & $-\mathrm{ve}$ & 96 & $\mathbf{S}$ \\
\hline 17 & JM17 & + & -ve rod & Lemon & $-\mathrm{ve}$ & $-\mathrm{ve}$ & $-\mathrm{ve}$ & $-\mathrm{ve}$ & 96 & $\mathbf{S}$ \\
\hline 18 & JM18 & + & -ve rod & Cream & $-\mathrm{ve}$ & $-v e$ & $-\mathrm{ve}$ & $-v e$ & 96 & $\mathbf{S}$ \\
\hline 19 & JM19 & + & -ve rod & Cream & $-\mathrm{ve}$ & $-\mathrm{ve}$ & $-\mathrm{ve}$ & $-v e$ & 96 & $\mathbf{S}$ \\
\hline 20 & JM20 & + & -ve rod & Cream & $-\mathrm{ve}$ & $-\mathrm{ve}$ & $-\mathrm{ve}$ & $-\mathrm{ve}$ & 96 & $\mathbf{S}$ \\
\hline 21 & JM21 & + & -ve rod & Off white & $-\mathrm{ve}$ & $-\mathrm{ve}$ & $-\mathrm{ve}$ & $-\mathrm{ve}$ & 96 & $\mathbf{S}$ \\
\hline 22 & JM22 & + & -ve rod & Off white & $-\mathrm{ve}$ & $-\mathrm{ve}$ & $-\mathrm{ve}$ & $-\mathrm{ve}$ & 96 & $\mathbf{S}$ \\
\hline 23 & JM23 & + & -ve rod & Off white & $-\mathrm{ve}$ & $-\mathrm{ve}$ & $-\mathrm{ve}$ & $-\mathrm{ve}$ & 96 & $\mathbf{S}$ \\
\hline 24 & JM24 & + & -ve rod & $\begin{array}{l}\text { Off } \\
\text { white }\end{array}$ & $-v e$ & $-\mathbf{v e}$ & $-v e$ & $-v e$ & 96 & $\mathbf{S}$ \\
\hline
\end{tabular}


Table. 2 Effect of treatments on germination $\%$, root length, shoot length, seedling length, dry weight and seed vigour index of winter chickpea

\begin{tabular}{|l|l|c|c|c|c|c|c|}
\hline Strain & Treatment & $\begin{array}{c}\text { Vigour } \\
\text { index }\end{array}$ & $\begin{array}{c}\text { Germin } \\
\text { ation \% }\end{array}$ & $\begin{array}{c}\text { Root length } \\
\text { cm }\end{array}$ & $\begin{array}{c}\text { Shoot } \\
\text { length cm }\end{array}$ & $\begin{array}{c}\text { Seedling } \\
\text { length cm }\end{array}$ & $\begin{array}{c}\text { Dry } \\
\text { weight }\end{array}$ \\
\hline JM & Control & 1261.06 & 83.67 & 11.67 & 7.00 & 17.67 & 15.02 \\
\hline JM-1 & Azotobacter & 1408.79 & 93.67 & 11.66 & 8.97 & 21.00 & 14.04 \\
\hline JM-2 & FYM & 1201.01 & 83.00 & 11.67 & 10.00 & 21.67 & 17.67 \\
\hline JM-3 & Ph+Azo+FYM & 1493.52 & 84.00 & 17.00 & 15.33 & 32.33 & 17.78 \\
\hline JM-4 & PSB & 1566.32 & 96.33 & 14.00 & 14.33 & 28.33 & 16.26 \\
\hline JM-5 & PSB.+ Azo & 1264.51 & 86.67 & 16.00 & 9.67 & 25.33 & 14.59 \\
\hline JM-6 & PSB + FYM & 1423.41 & 92.67 & 15.67 & 13.00 & 28.67 & 15.36 \\
\hline & S.Ed. \pm & - & 1.53 & 1.38 & 0.90 & 1.53 & 0.17 \\
\hline & C.D. at 5\% & - & 3.33 & 2.99 & 1.96 & 3.32 & 0.37 \\
\hline
\end{tabular}

\section{RFLP (Restriction fragment length polymorphism)}

The PCR products were individually restricted with endonucleases (Alu-I) showed the discriminative banding pattern ranging from 100- 9000 bp (Fig. 4) Similarity and dissimilarity co-efficient were analyzed by UPGMA (Malviya et al., 2012) Cluster analysis among the isolates JM18, JM17, JM7, JM8, JM22, JM10, JM9, JM14, JM6, JM24, JM23, JM12, JM11, JM4, JM3, JM1, JM2 and JM20 showed $100 \%$ similarity and JM18-JM7 showed 20\%, dissimilarity however strain JM6-JM22 showed 24\% dissimilarity among the strain JM24-JM3 showed $25 \%$ the ornamentation of strains between JM1-JM12 were shows 26\% dissimilarity among the isolates (Fig. 5)

RAPD analysis random amplified (OPK 20) 5'-GTGTCGCGAG-3' was selected because it was able to differentiate among isolates (Malviya et al., 2012) (Fig. 6).

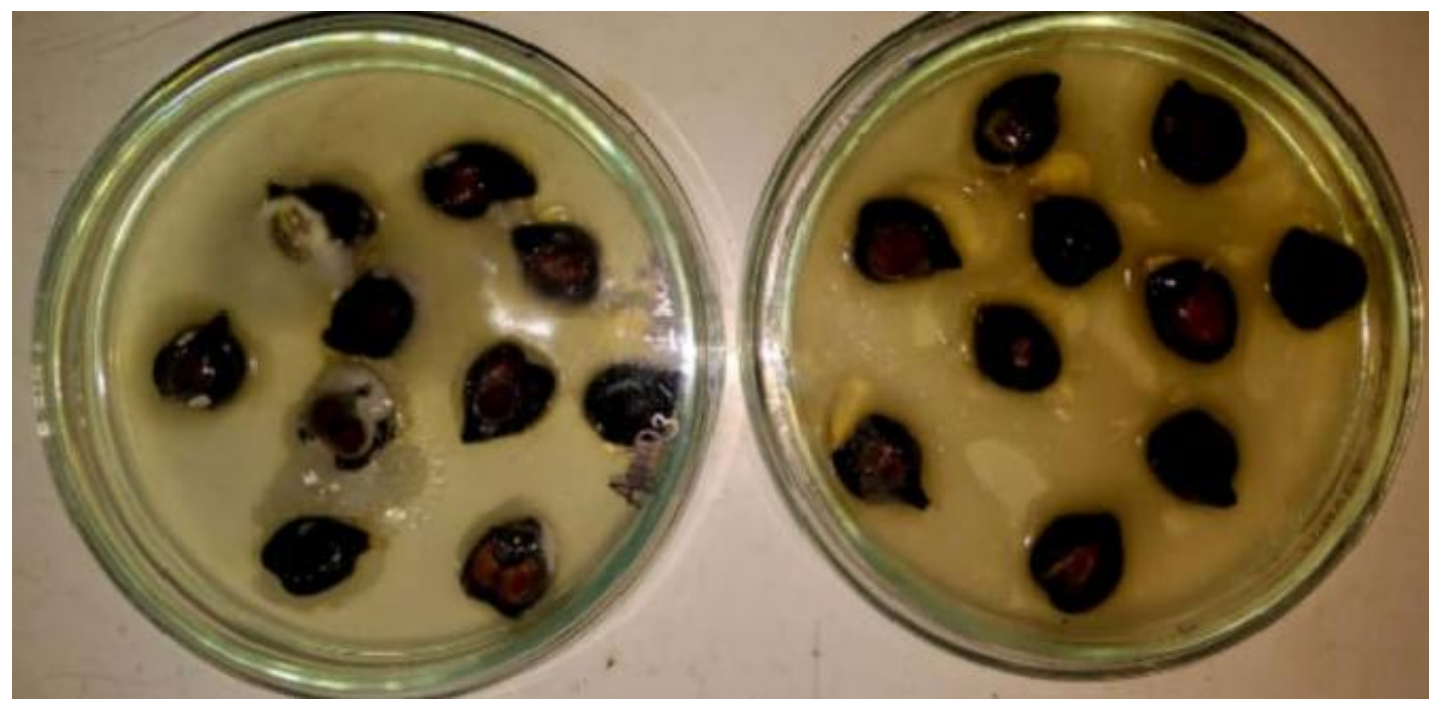

Fig.1 Germination of Cicer arietinum in the presence of Azotobacter culture 


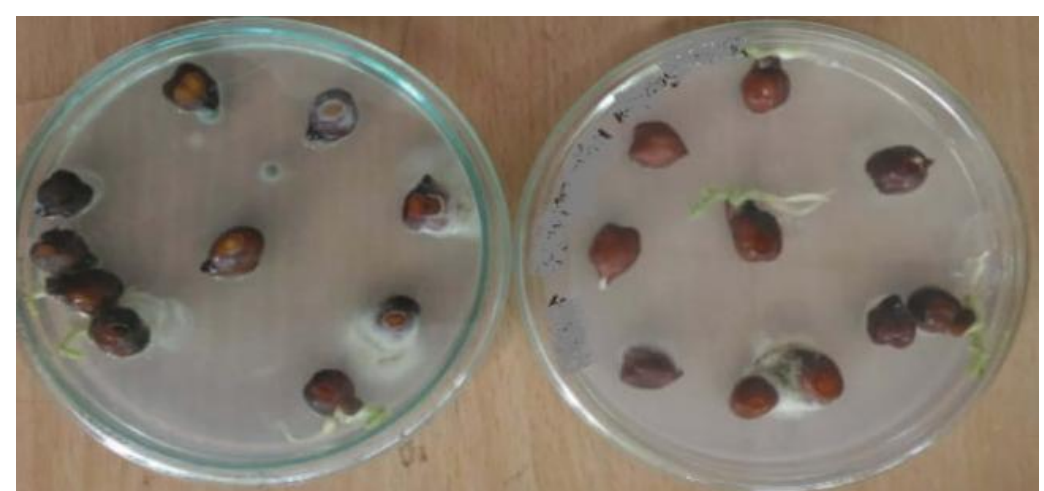

Fig.2 Germination of rhizome of Cicer arietinum in the presence of Azotobacter culture

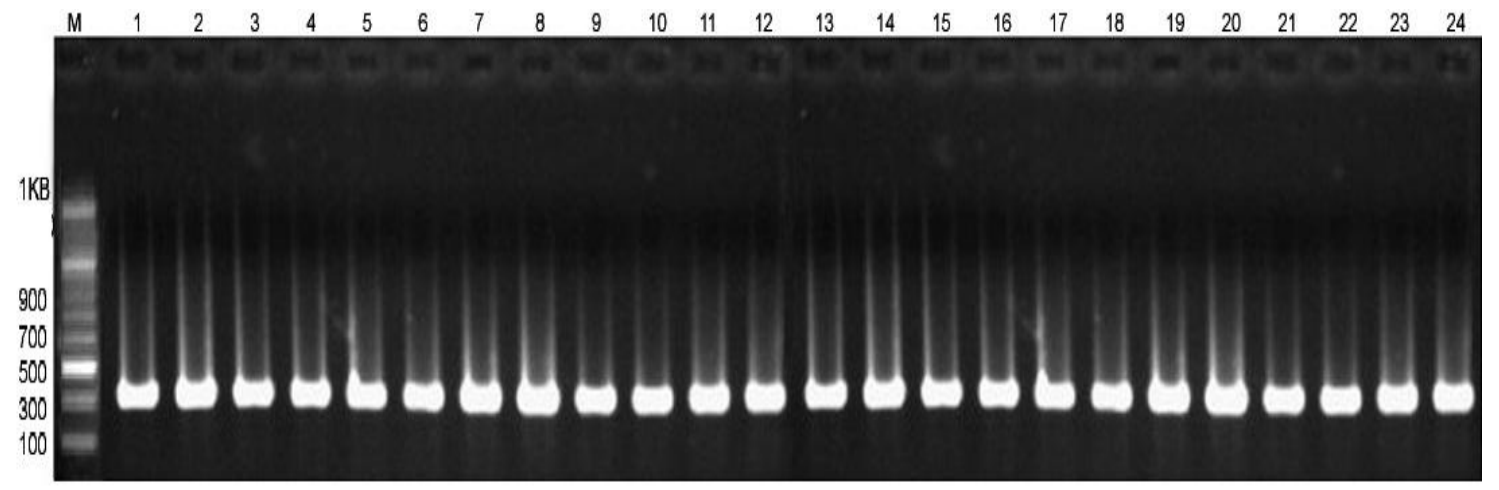

Fig.3 Isolated DNA of Azotobacter species on 2\% Agarose gel

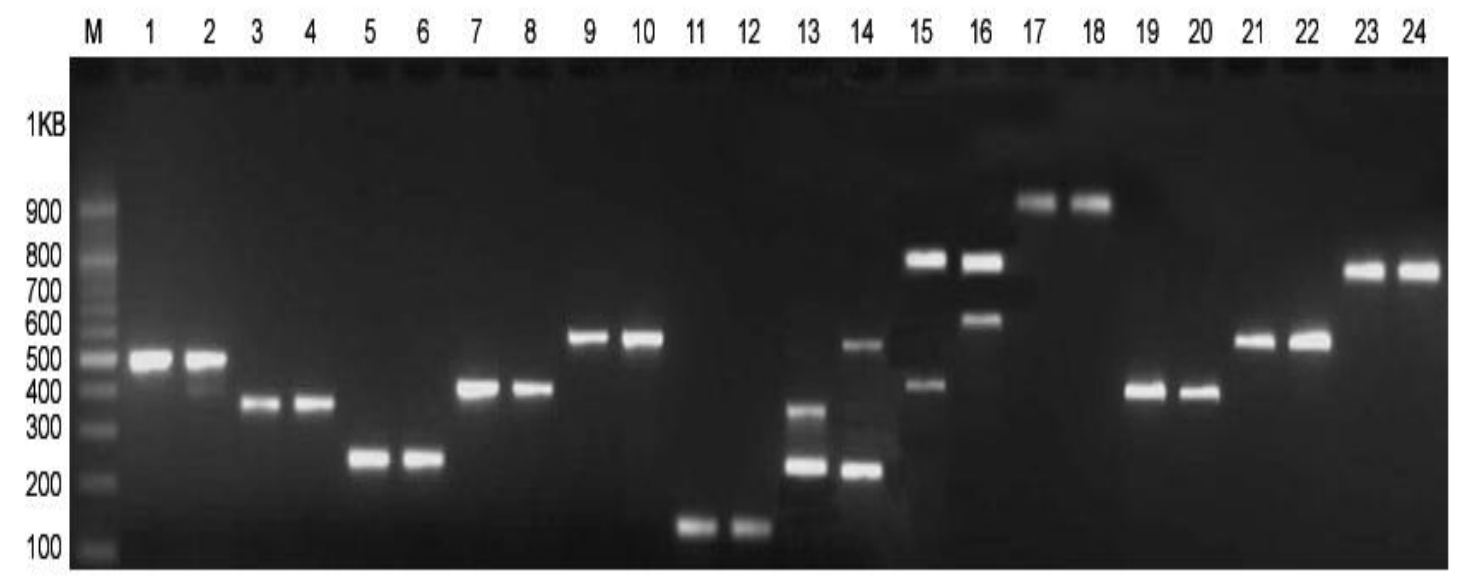

Fig.4 RFLP amplification of Azotobacter species on 2\% Agarose gel

\section{Scoring and data analysis}

The unweighted combine aggregate built Dendogram from the closeness organize. Method with number shuffling mean averaging (UPMGA) (Sneath and sokal 1973). With the ultimate objective to test the honesty of assault of gathering examination, cophenetic regard arrange were found out and differentiated and the main closeness grid that were UPMGA clustered by using the NTSYSpc assessment pack (Version 1.3, Exeter programming Setauket, N.Y.) (Malviya et al., 2012). 


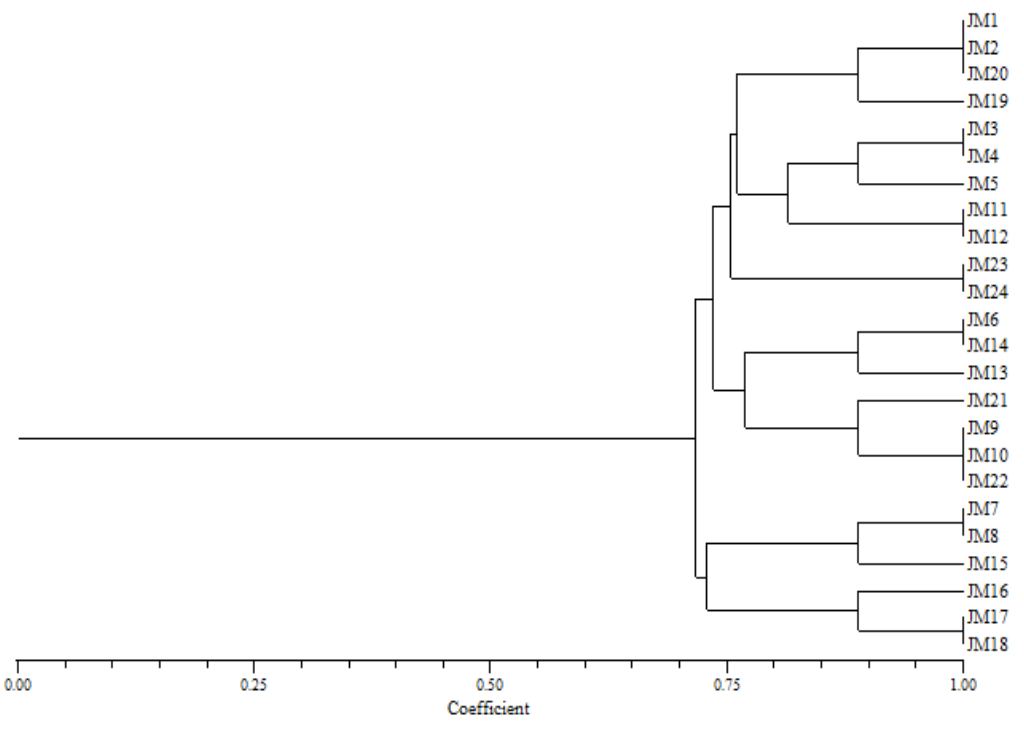

Fig.5 Cluster analysis of RFLP pattern with NTSYs software

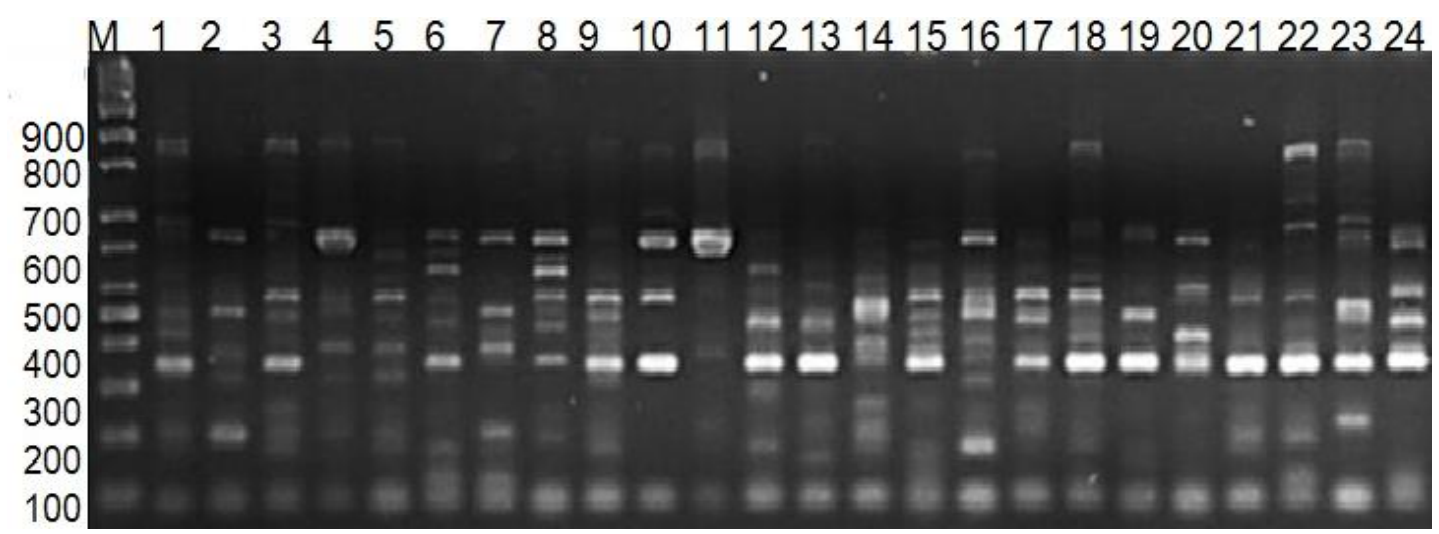

Fig.6 RAPD amplification of Azotobacter species on 2\% Agarose gel

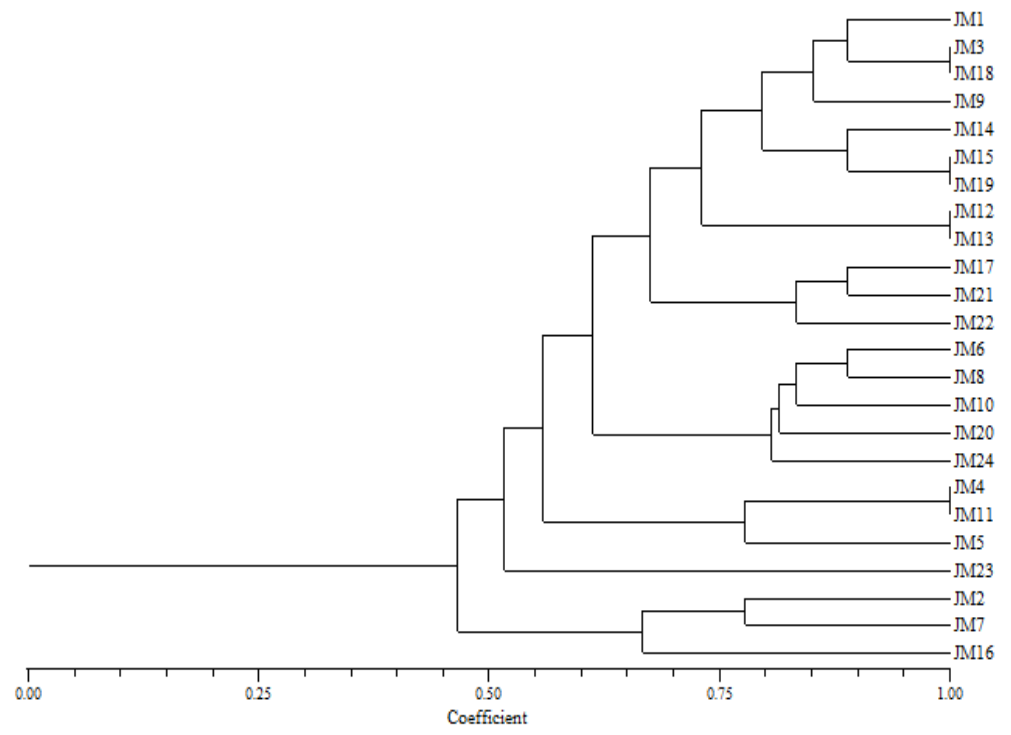

Fig.7 Cluster analysis of RAPD pattern with NTSYs software 
Likeness and difference co-effective were broke down by UPGMA Cluster investigation among the detaches 2,7 and 16 are half comparative among all disconnects 4 and 11, 12 and 13, 03 and 16, 15 and 19 are gave $100 \%$ similitude appeared to one another. The likeness coefficient demonstrates the conveyance of comparability record with in the separates indicated a potential (Fig. 7).

Experimentation recommends that PCR can effectively estimate the development natural surroundings and geographic beginning. Investigations of (Iruela et al., 2002) in the variety Cicer and developed chickpea utilizing mix of RAPD and ISSR markers of 26 promotions including kabuli and desi types were utilized. (Rao et al., 2007) created RAPD and ISSR fingerprinting in developed chickpea and its wild ancestor Cicer reticulatum $\mathrm{L}$.

They finished up ISSR examination as dependable traits for estimation of hereditary decent variety than of RAPD. (Fatemeh et al., 2013) utilized ISSR markers to unique mark hereditary decent variety and preservation of landrace chickpea from north-west of Iran. ISSR markers are adequately scored for hereditary assorted variety investigation of different harvest plants. (Amirul et al., 2015) evaluated hereditary decent variety among gathered purslane promotions. In view of their evaluation they suggested not many of the promotion that can be utilized as guardians in future reproducing program.

In the present experiment, the Chickpea being a self-pollinated crop has a tight hereditary base. Taking a gander at gigantic chickpea germplasm accessible and to diminish expenses of field experimentation, genotype screening utilizing PCR based markers is an essential for reproducing program. In view of hereditary root and decent variety list viz. prescribed to be chosen as a parent in future rearing projects for chickpea. More endeavors are expected to screen chickpea promotions which can evaluate hereditary decent variety inside the Cicer species to recognize first class hereditary stocks.

\section{References}

Iruela M, Rubio J, Cubero JI, Gil J, Millán T (2002). Phylogenetic analysis in the genus cicer and cultivated chickpea using RAPD and ISSR markers. Theor Appl Genet 104: 643-651.

Malviya, J, K Singh (2012) Characterization of novel plant growth promoting and biocontrol strains of fluorescent Pseudomonads for crop. Int J Med Res. 1: 235-244

Jitendra Malviya (2018) Bacterial diversity of phosphate availability on growth and nutrient uptake of chickpea (Cicer arietinum l.) crops. International Journal of Creative Research Thoughts. 6:296-311

Jitendra Malviya, Bhupendra Prasad and Shivendra Kumar Chaurasiya (2017) Genome based comparative study of pseudomonas species. RJLBPCS. 3:197-193

Jitendra Malviya, Kiran Singh (2011) Effect of phosphate solubilizing fungi on growth and nutrient uptake of ground nut (Arachis hypogaea) plants. Adv. Biores 2:110-113

Jitendra Malviya, Kiran Singh (2012) Biogeography and Polyphasic Approach of Pseudomonas strains from Agriculture land of Madhya Pradesh. Advances in Life Science and Technology 5:43-57.

Md Amirul A, Abdul SJ, Rafii MY, Azizah AH, Arolu IW, et al., (2015) Genetic diversity analysis among collected purslane (Portulaca oleracea L.) accessions using ISSR markers. Comptes Rendus Biol 338: 1-11. 
Pakseresht F, Talebi R, Karami E (2013) Comparative Assessment of ISSR, DAMD and SCoT Markers for Evaluation of Genetic Diversity and Conservation of Landrace Chickpea (Cicer arietinum L.) Genotypes Collected from North West of Iran. Physiol Mol Biol Plants 19: 563-574.

Rao L, Usha RP, Deshmukh P, Kumar P, Panguluri S (2007) RAPD and ISSR Finger-Printing in Cultivated Chickpea (Cicer arietinum L.) and Its
Wild Progenitor Cicer reticulatum Ladizinsky. Genetic Resources and Crop Evolution 54: 1235-1244.

Tibayrenc, M., Neubauer, K., Barnabe, C., Guerrini, F., Skarecky, D., Ayala, F. J. (1993). Genetic characterization of six parasitic protozoa: Parity between random-primer DNA typing and multilocus enzyme electrophoresis. Proceedings of the National Academy of Sciences (USA). 90: 1335-1339.

\section{How to cite this article:}

Jitendra Malviya and Bhupendra Prasad. 2020. Microbial Diversity among Azotobacter Strains and Efficacy Test on Chickpea (Cicer arietinum). Int.J.Curr.Microbiol.App.Sci. 9(04): 11031115. doi: https://doi.org/10.20546/ijcmas.2020.904.131 